\title{
E-BUSINESS, ORGANIZATIONAL INNOVATION AND FIRM PERFORMANCE IN MANUFACTURING SMES: AN EMPIRICAL STUDY IN SPAIN
}

\author{
Pedro SOTO-ACOSTA ${ }^{\mathrm{a}}$, Simona POPA ${ }^{\mathrm{a}}$, Daniel PALACIOS-MARQUÉS ${ }^{\mathrm{b}}$ \\ ${ }^{a}$ Department of Management and Finance, University of Murcia, \\ Campus de Espinardo, 30100 Murcia, Spain \\ ${ }^{b}$ Department of Business Administration, Polytechnic University of Valencia, \\ Camino Vera s/n, 46022 Valencia, Spain
}

Received 19 August 2014; accepted 16 May 2015

\begin{abstract}
This paper extends previous studies on the organizational impact of Internet technologies by analyzing factors affecting e-business use and its effect on organizational innovation in manufacturing Small and Medium-Size Enterprises (SMEs). In addition, the mediating effect of organizational innovation on the relationship between e-business and firm performance is analyzed. Grounded in the Technology-Organization-Environment (TOE) theory and the Knowledge-Based View (KBV), this paper develops an integrative research model which analyzes those relations using partial least squares (PLS) structural equation modeling on a dataset of 175 Spanish manufacturing SMEs. Results suggest that e-business use emerges from technological and internal organizational resources rather than from external pressure. In addition, results show that e-business use contributes positively to firm performance through organizational innovation.
\end{abstract}

Keywords: e-business, organizational innovation, firm performance, manufacturing, SMEs, TOE framework, knowledge-based view, SEM, PLS.

JEL Classification: L250, M150, O140, O310.

\section{Introduction}

The current economic context, characterised by the acceleration of technological change, globalization and competitive intensity, has put increasing pressure upon the management of small and medium-size enterprises (SMEs), especially manufacturing SMEs which must today compete globally (Lopez-Nicolas, Soto-Acosta 2010; Raymond et al. 2005). The importance of manufacturing SMEs for economic growth, employment and wealth creation has been widely acknowledged (Devaraj et al. 2007; Jardim-Goncalves et al. 2012). For

Corresponding author Pedro Soto-Acosta

E-mail:psoto@um.es 
instance, in Europe, SMEs represent over $80 \%$ of the total number of firms within the manufacturing sector, accounting for around $60 \%$ of the employment (European Commision 2013).

With the technological revolution brought by the Internet, manufacturing firms are migrating toward e-business technologies in order to lower their operating costs, raise productivity and quality, and respond rapidly to their customers' and other business partners' requirements (Jardim-Goncalves et al. 2012; Raymond et al. 2005). As a result, effective adoption and use of e-business technologies have become major management concerns (Soto-Acosta, Meroño-Cerdan 2008; Meroño-Cerdan et al. 2008b). Moreover, although businesses have extensively adopted e-business technologies, actual use is an important link to business value and such a link has been found to be especially lacking in SMEs (Devaraj, Kohli 2003). However, studies in the literature tend to examine e-business in large businesses, with very few recent studies analyzing SMEs (e.g. Chan et al. 2012; Chong et al. 2009), while it is even less common to find studies analyzing e-business use in manufacturing SMEs (Raymond et al. 2005).

Furthermore, although recent works are starting to analyze the adoption and use of e-business within organizations and how these technologies support specific business processes, much of the existing research focuses on a single view of e-business use (Gu et al. 2012; Soto Acosta et al. 2014a, 2014b), with very few studies examining the use of e-business along the whole value chain. Thus, it is important to understand the key factors that facilitate and motivate the use of e-business along the value chain within manufacturing SMEs. Competitive pressure has been defined in various studies as a key determinant of firm's readiness to accept new technology (Bayo-Moriones, Lera-Lopez 2007; Sila 2013; Teo et al. 2006). At the same time, the literature considers that technological factors are important drivers for the adoption and implementation of IT innovations (Aboelmaged 2014; Acker 2014; Palacios-Marqués et al. 2015; Ramdani et al. 2013). However, beyond technological and the environmental factors, research has recognized the importance of organizational factors in influencing Internet technologies adoption and use (Aboelmaged 2014; Gu et al. 2012; Kim et al. 2011; Lian et al. 2014; Sila 2013). Organizational factors may restrict or facilitate the implementation and usage of Internet technologies. In this sense, the literature suggests that organizational human resource (HR) practices that create a commitment-based environment influence the interactions, behaviours and motivation of employees (Collins, Smith 2006). HR practices may therefore affect the organizational social climate which motivates employees to work together and collaborate by being organizational enablers of technology use (Soto Acosta et al. 2014a) Moreover, although there is recent research analyzing the relationship between e-business and organizational innovation and the relationship between e-business and firm performance (e.g. Bordonaba-Juste et al. 2012; Lucia-Palacios et al. 2014; Zhu, Kraemer 2005), to the best of our knowledge, no research has analyzed whether and how different factors promote or hinder e-business use in manufacturing SMEs and the effect of e-business use on organizational innovation and performance in a single integrative model.

To respond to the above gaps in the literature, this paper develops a research model, grounded on the Technology-Organization-Environment (TOE) framework and the 
Knowledge-Based View (KBV), to analyze the key factors that facilitate e-business use and its effect on organizational innovation and firm performance within manufacturing SMEs. The paper consists of six sections and is structured as follows: The next section presents the literature review and hypotheses. Following that, the methodology used for sample selection and data collection is discussed. Then, data analysis and results are examined. Finally, the paper ends with a discussion of research findings, limitations and concluding remarks.

\section{Theoretical background and hypotheses}

The technology-organization-environment (TOE) framework (Tornatzky, Fleischer 1990) has been extensively used as the theoretical framework to analyze factors which affect the adoption and use of different e-business technologies including: a) cloud computing (e.g. Hsu et al. 2014; Lian et al. 2014); b) collaborative technologies (eg. Chan et al. 2012), c) mobile commerce (e.g. San Martín et al. 2012); and d) enterprise resource planning (e.g. Bradford et al. 2014; Zhu et al. 2010). The TOE framework has also emerged as the main theoretical framework to analyze the different factors which affect the adoption and use of e-business at the firm level of analysis (e.g. Bordonaba-Juste et al. 2012; Lucia-Palacios et al. 2014). The TOE framework conceives the context of adoption and implementation of technological innovations as consisting of three factors: the technological context, the organizational context and the environmental context. The technological context refers to the characteristics of the technological innovation, the organizational context describes characteristics of the organizations, and the environmental context implies characteristics of the environment in which the adopting organizations operate (Tornatzky, Fleischer 1990; Thong 1999). Thus, drawing upon literature analyzing e-business adoption and use, this paper, based on the TOE framework, analyzes the factors that influence e-business use.

The Knowledge-Based View (KBV) regards knowledge as the most strategic resource of a firm and argues that, because it consists heterogeneous knowledge bases and capabilities, it is usually difficult to imitate and socially complex and, therefore, with potential to generate sustained competitive advantage and superior corporate performance (Grant 1996, 2002; Kogut, Zander 1992; Nickerson, Zenger 2004). The KBV is in reality an extension of the Resource-Based View (RBV). The RBV has become a standard to explain why firms in the same industry vary systematically in performance over time (Hoopes et al. 2003). This suggests that the effects of individual, firm-specific resources on performance can be significant (Mahoney, Pandian 1992). The RBV generally tends to define resources broadly and includes assets, infrastructure, skills, and so on. In this regard, it is based on two underlying assertions: resource heterogeneity and resource immobility. Resources possessed by competing firms are heterogeneously distributed and may be a source of competitive advantage when they are valuable, rare, difficult to imitate, and not substitutable by other resources (Barney 1991). At the same time, resources are a source of sustained competitive advantage, that is, differences may be long lasting (resource immobility) when protected by barriers to imitation (Mahoney, Pandian 1992) or isolating mechanisms such as time-compression diseconomies, historical uniqueness, embeddedness and causal ambiguity (Barney 1991; Peteraf 1993). Physical technology is by itself typically imitable and, thus, such tools 
should not be a source of competitive advantage (Barney 1991). However, as argued by Soto-Acosta, Meroño-Cerdan (2008: 51) "the combination of Internet resources and other valued corporate resources, and their integration in the organizational processes, may lead to better firm performance". Thus, this paper, from a knowledge-based perspective, studies the relationship between e-business use, organizational innovation and firm performance as well as the mediating effect of organizational innovation on the relationship between e-business and firm performance.

\subsection{TOE framework and e-business}

E-business technology is today widely spread among organizations. In this scenario, Information Technology (IT) integration plays a pivotal role in supporting organizational e-business processes and, thus, the extent of e-business use depends on firms' IS integration. Technology integration refers to a firm ability to effectively transform common technologies into capabilities (Soto-Acosta, Meroño-Cerdan 2008). Information Systems (IS) integration has been found significant in studies using the TOE framework (e.g. Zhu et al. 2006; Zhu, Kraemer 2005). IT integration in the e-business context is conceptualized as front-end integration and back-end integration (Zhu et al. 2004). Front-end and back-end integration are built on common Internet technologies in use (intranet, website and extranet...) and are important antecedents of e-business since they enable communications, collaboration and the automation of business processes. IS integration is key for ebusiness within manufacturing firms because they require the streamline of data along the value chain (e.g. manufacturing and inventory systems of the firm and their suppliers and customers) (Zhu et al. 2006). Therefore, IS integration may be an important technological issue to explain the extent of e-business use within manufacturing SMEs. The following hypotheses incorporate our expectations:

Hypothesis 1: There is a positive relationship between IS integration and the extent of ebusiness use.

Technology enablers are a necessary but not sufficient condition for employees to collaborate through e-business technologies. E-collaboration happens when units and members interact electronically, promoting new understanding (Alavi, Leidner 2001). It is therefore essential for the firm to develop interaction networks (Lee, Kim 2014). However, besides technology applications, employees need to be willing to collaborate and share knowledge (Shi 2013). Social exchange theory argues that employees balance their level of commitment with the company's level of commitment to them (Wayne et al. 1997). Thus, building a positive social climate may be crucial to motivate employees to work together through electronic networks (Valkokari et al. 2012) and increase e-business use for collaboration and knowledge sharing. This is even more crucial when exchanging tacit knowledge, which requires more interaction (Fox 2000). The literature distinguishes between transaction-based HR practices, which focus on individual short-term exchange relationships, and commitment-based HR practices, which emphasize mutual long-term exchange relationships (Palacios-Marqués et al. 2015; Tsui et al. 1997). As a consequence, recent research has found that commitment-based HR practices are determinants of knowledge sharing 
through web and web 2.0 technologies (Soto Acosta et al. 2014a, 2014b). Based on this discussion, the following hypothesis is proposed:

Hypothesis 2: There is a positive relationship between Commitment-based HR practices and the extent of e-business use.

Competition intensity has been found to be an important driver of Internet technologies adoption so as to remain competitive (Chong et al. 2009; Wang et al. 2010; Zhu et al. $2003,2006)$. In this sense, studies have found that horizontal competition drives organizations to adopt e-business (Del Aguila-Obraz, Padilla-Melendez 2008; Wang, Ahmed 2009). However, research (e.g. Chan et al. 2012; Zhu et al. 2006) has also shown that horizontal competition may deter firms from using Internet technologies, so challenging the traditional wisdom about competition and innovation diffusion. Zhu et al. (2006) found a positive relation between horizontal competition and e-business adoption, but a negative relation between horizontal competition and the extent of e-business use. Similarly, Chan et al. (2012) found that competition intensity is negatively related to the extent of e-collaboration use in SMEs. Thus, e-business use is less tied to horizontal competition intensity than initially thought in both large and small business. In fact, too much competitive pressure leads firms to change rapidly from one technology to another without sufficient time to make the most of technology, since that continuous change may impede firms from learning how to use existing technological applications effectively (Zhu et al. 2006). Moreover, horizontal competition does not merely come from existing competitors in an industry but also from substitutes (Porter 1985). This discussion leads to the following hypothesis regarding horizontal competition and the extent of e-business use:

Hypothesis 3: There is a negative relationship between horizontal competition and the extent of e-business use.

\subsection{E-business, organizational innovation and firm performance}

Defining the concept of innovation is not straightforward because this subject has been studied from different approaches: technological, organizational, administrative, etc. However, there seems to be a consensus to treat innovation as new knowledge and ideas transformed into new products and/or services, new technologies, new processes and new organizational forms or structures (Damanpour 1991; He, Wong 2004). For long time there has been extensive theoretical argumentation concerning the capabilities of IT to drive significant innovations in business processes, products and services of firms, and through them result in big improvements of their business performance (Bresnahan et al. 2002; García-Peñalvo et al. 2011; Soto-Acosta et al. 2011). Moreover, the ability to innovate, especially in dynamic environments, results from the collective ability of employees to share and combine knowledge (Nahapiet, Goshal 1998). In this sense, there are a number of studies that link innovation to inter-functional coordination and the use of networks (Darroch 2005; Ramayah et al. 2014; Soto-Acosta et al. 2014a). Firms are using more and more collaborative technologies (shared databases, repositories, discussion forums, workflow...) for the execution of the innovation process (Meroño-Cerdan et al. 2008a). As a consequence, Meroño-Cerdan et al. (2008b) found that most collaborative technologies 
are positively related to innovation in SMEs. Similarly, other Internet technologies can be used for knowledge sharing such as the extranet and the web site, for instance, with customers and suppliers (Soto-Acosta et al. 2014a). Thus, Internet technologies can be used to distribute and share individual experience and innovation throughout the organization (Bhatt et al. 2005; Soto-Acosta et al. 2010) and offer the chance of applying knowledge for the creation of new products and/or services or processes. Moreover, these technologies facilitate the formation of virtual teams to execute the innovation process with users and partners from remote places (Adamides, Karacapilidis 2006; Kessler 2003). In sum, the benefits from e-business use, which include efficient information and knowledge sharing as well as working with no distance limitations, are expected to be positively related to innovation. Thus, the following hypothesis is proposed:

Hypothesis 4: There is a positive relationship between the extent of e-business use and organizational innovation.

Furthermore, research has found a positive link between certain Internet technologies (collaborative technologies, the website) and firm performance (e.g. Meroño-Cerdan et al. 2008a; Meroño-Cerdan, Soto-Acosta 2005, 2007; Xin et al. 2014), while other studies have found that Web knowledge sharing is an antecedent of innovation (Soto-Acosta et al. 2014). The ability to create new knowledge through Web knowledge sharing may enable firms to improve firm performance through innovation. In this sense, there are also studies that have examined the importance of Internet technologies for knowledge creation (e.g. Lopez-Nicolas, Soto-Acosta 2010) and the relationship between IT, knowledge management and firm performance (e.g. López-Nicolás, Meroño-Cerdán 2011; Pérez-López, Alegre 2012), finding positive direct and indirect links between IT, knowledge management and firm performance. Thus, organizational innovation may mediate the relationship between the extent of e-business use and firm performance (see Fig. 1). The following hypothesis is formulated:

Hypothesis 5: Organizational innovation mediates the relationship between the extent of e-business use and firm performance.

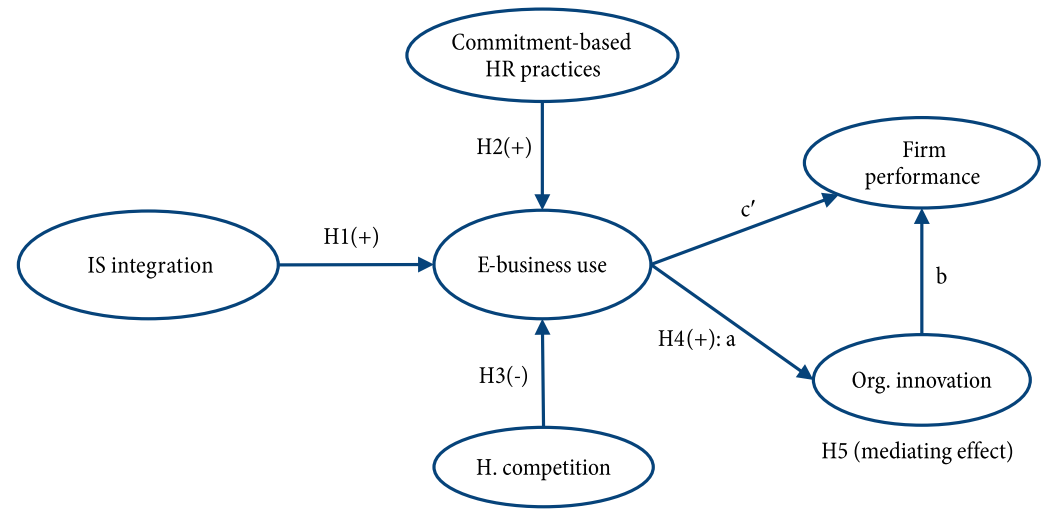

H5: Organizational innovation mediates the relationship between e-business use and firm performance

Fig. 1. Research model 


\section{Research methodology}

\subsection{Data collection and sample}

The organisations selected for this study are SMEs from Spain. Previous research in the Spanish context (e.g., Meroño-Cerdan et al. 2008a, 2008b) suggested that using IT is crucial for firms with at least 10 and over. To ensure a minimum firm complexity in which ITs may be relevant, the population considered in this study was the set of all Spanish enterprises, with at least 15 employees, located in the South-east of the country whose primary business activity is manufacturing. Data collection was conducted in two stages: a pilot study and a questionnaire were conducted. Five SMEs were randomly selected from a database to pretest the questionnaires. Based on these responses and subsequent interviews with participants in the pilot study, minor modifications were made to the questionnaire for the next phase of data collection. Responses from these five pilot-study firms were not included in the final sample.

The population considered in this study was the set of all Spanish enterprises, with at least 15 employees, located in the southeast of the country whose primary business activity is manufacturing. A total of 1291 were identified and contacted for participation. The survey was administered in face-to-face interviews with to the CEO of the companies and the unit of analysis for this study was the company. In total, 175 valid questionnaires were obtained, yielding a response rate of 13.55 percent. The dataset was examined for potential bias in terms of non-response by comparing the characteristics of early and late participants in the sample. These comparisons did not reveal significant differences in terms of general characteristic and model variables, suggesting that non-response did not cause any survey bias.

\subsection{Measures}

Measurement items were introduced on the basis of a careful literature review. The survey questionnaire was originally designed in English as the key measures used in this study were operationalized using already established instruments published in that language. Scales were measured on a 5-point Likert scale with anchors from strongly disagree (1) to strongly agree (5). We used the back-translation method to ensure the validity of the translation (Brislin 1980). Existing scales were translated into Spanish and, where necessary, slight wording changes were made to adapt the questions to the context of the study. The research instrument was pretested with five different researchers and managers. Our primary objective was to detect inadequate wording and facilitate the ease of administering the instrument. The results from the pretest showed no particular bias, but some respondents had trouble understanding certain items.

Variables were operationalized as multi-item constructs. The extent of e-business use measured the use of e-business to conduct or support business process along the value chain: product design, manufacturing, logistics, marketing/sales, after-sales service (Zhu, Kraemer 2005; Zhu et al. 2006). IS integration assessed the extent to which the website is connected with back-end information systems and databases, and the extent to which company databases are linked to business partners' systems and databases. Items for IS 
integration are based on Zhu et al. (2006). Horizontal competition was measured following Porter's (1985) conceptualization of horizontal competition: threat of existing competitors and substitute products. Commitment-based HR practices were operationalized based on Collins and Smith (2006), Delery and Doty (1996) and Youndt et al. (1996) as a second-order single consisting of two dimensions: training support and employees interest (CHRP1) and career plans and evaluation reporting (CHRP2). Organizational innovation was measured following items in previous studies (Antoncic, Hisrich 2001; Becheikh et al. 2006; Soto-Acosta et al. 2014a) and represents firms' emphasis on research and development and new technological knowledge and ideas into new products and processes. Firm performance was operationalized using items in previous works (Aragón-Correa et al. 2008; Judge, Douglas 1998) through which respondents rated their organization's performance relative to others in the industry. Firm performance was operationalized as a single construct made up of two dimensions: 1) financial performance; and 2) customer satisfaction and customer perceived product quality. Perceptual measures of firm performance has been previously used in the literature analyzing SMEs because objective data on the firm performance of these firms are rarely available, largely because the owners are not legally required to publish these data (Lubatkin et al. 2006). In addition, this approach was followed because it is generally assumed that CEOs are knowledgeable informants, particularly with regard to their firms' performance. Moreover, evidence suggests that CEO self-reports of performance significantly correlate with objective measures of firm performance (Chang, Hughes 2012; He, Wong 2004). The formulation and criteria for answering the questionnaire are defined in the Appendix.

\subsection{Common method variance}

We used Structural Equation Modelling (SEM) for measurement validation and testing the structural model. SEM is particularly useful for testing complex models and when researchers need to incorporate latent variables. More specifically, we opted to use SEM based on Partial Least Squares (PLS) approach because the variance-based PLS method is preferable to the covariance-based when sample sizes are small and it can incorporate both reflective and formative measures (Chin et al. 2003). The general rule of thumb regarding appropriate sample size when using PLS is to multiply by ten the number of indicators on the most complex construct or the largest number of paths leading to a dependent construct in the model. In the proposed model, the highest number of paths leading to a dependent variable is four, while the number of indicators on the most complex is seven (Barclay et al. 1995). Thus, according to this rule, the minimum sample size necessary would be 70 . With 175 responses, the PLS analysis appears to have sufficient power.

Since we collected both independent and dependent variables simultaneously from the same respondents, common method variance could be a concern in this study. The extent of common method bias was assessed by using four different methods. First, the Harman's one-factor test was used by entering all the indicators into a principal components factor analysis (Podsakoff, Organ 1986). Evidence for common method bias exists when a general factor accounts for the majority of the covariance among all factors. With all indicators 
entered, 7 factors were extracted. The variance explained ranged from $24 \%$ to $4 \%$, indicating no substantial common method bias. Second, a partial correlation method was used (Podsakoff, Organ 1986). The highest factor from the principal component factor analysis was added to the Partial Least Square (PLS) model as a control variable on all dependent variables. According to Podsakoff and Organ, this factor is assumed to "contain the best approximation of the common method variance if is a general factor on which all variables load" (Podsakoff, Organ 1986: 536). This factor did not produce a significant change in variance explained in any of the three dependent variables, again suggesting no substantial common method bias. Third, we used Lindell and Whitney's (2001) method, which employs a theoretically unrelated construct (marker variable) to adjust the correlations among the principal constructs. Diversity (Armstrong et al. 2010) was used as the marker variable. Any high correlation among any of the items of the study's principal constructs and social cohesion would be an indication of common method bias, as diversity is weakly related to the study's principal constructs. Since the average correlation among diversity and the principal constructs was $r=0.049$, this test showed no evidence of common method bias. Fourth, the correlation matrix (Table 1) did not indicate any highly correlated variables, while evidence of common method bias usually results in extremely high correlations ( $\mathrm{r}>$ 0.90) (Bagozzi et al. 1991). In summary, these tests suggest that common method bias is not a serious threat in our study. Table 1 also provides an overview of the means, standard deviations and correlations of the constructs.

Table 1. Descriptives statisticts and discriminant validity

\begin{tabular}{|c|c|c|c|c|c|c|c|c|c|c|}
\hline \multirow{2}{*}{ Constructs } & \multirow{2}{*}{ Av } & \multirow{2}{*}{$\mathrm{Sd}$} & \multicolumn{7}{|c|}{ Correlation matrix } & \multirow[b]{2}{*}{$(8)$} \\
\hline & & & $(1)$ & $(2)$ & $(3)$ & $(4)$ & $(5)$ & (6) & $(7)$ & \\
\hline 1. IS Integration & 2.7 & 1.2 & 0.80 & & & & & & & \\
\hline 2. $C H R P 1$ & 3.7 & 0.8 & 0.07 & 0.65 & & & & & & \\
\hline 3. $C H R P 2$ & 3.4 & 0.9 & $0.42^{* *}$ & $0.30^{* *}$ & 0.71 & & & & & \\
\hline 4. Competition & 3.2 & 1.2 & $0.26^{\star *}$ & -0.03 & $0.17^{* *}$ & n.a. & & & & \\
\hline 5. E-business $U$. & 3.3 & 0.9 & $0.45^{\star *}$ & $0.16^{*}$ & $0.43^{* *}$ & $0.16^{* *}$ & 0.72 & & & \\
\hline 6. Innovation & 3.5 & 0.9 & 0.06 & $0.33^{* *}$ & $0.13^{*}$ & -0.02 & $0.28^{* *}$ & 0.67 & & \\
\hline 7. Firm Perf. 1 & 3.2 & 0.7 & 0.08 & $0.36^{* *}$ & $0.22^{* *}$ & 0.02 & $0.27^{* *}$ & $0.29^{* *}$ & 0.70 & \\
\hline 8. Firm Perf. 2 & 4.0 & 0.7 & 0.15 & $0.35^{* *}$ & $0.33^{* *}$ & 0.07 & $0.41^{* *}$ & $-0.37^{\star *}$ & $0.46^{* *}$ & 0.8 \\
\hline
\end{tabular}

Notes: Significance levels: $p<0.05^{*} ; p<0.01^{* *}$; A.V: Average Value; S.D. $=$ Standard Deviation n.a. AVE is not applicable to formative constructs. Diagonal values in bold represent the square root of the AVE.

\subsection{Instrument validation}

Before testing the proposed model, it is necessary to verify the reliability and validity of the measurement model (Barclay et al. 1995). Convergent validity of the scales is contingent on the fulfillment of three criteria (Fornell, Larker 1981; Hair et al. 1998): (1) all indicator loadings should exceed 0.65 (2) Composite Reliabilities (CR) should exceed 0.8; and (3) the average variance extracted (AVE) for each construct should exceed 0.5. As Table 2 shows, 
all the indicator loadings are above the recommended threshold, the CR values range from 0.87 to 0.95 , and the AVE ranges from 0.55 to 0.82 . All three conditions for convergent validity thus hold.

To evaluate discriminant validity, Fornell and Larker (1981) suggest that the square root of the AVE of a latent variable should be greater that the correlations between the rest of the latent variables. As Table 1 shows, discriminant validity holds for the model, as the square root of the AVE for each construct is greater than the correlations between the variables that form the construct. Furthermore, the Cronbach's alpha values of all indicators should exceed the recommended value of 0.6 (Nunnally 1967) and all our measurement items noted in Table 2 exceed 0.6. Thus, overall measurement items have adequate item reliability.

Table 2. Reliability and convergent validity

\begin{tabular}{|c|c|c|c|c|}
\hline Construct & Item loading ${ }^{\mathrm{a}}$ & t-statistic & Cronbach's Alpha & CR\&AVE \\
\hline \multicolumn{5}{|l|}{ IS integration } \\
\hline IS1 & 0.88 & 32.57 & \multirow[t]{2}{*}{0.76} & $\mathrm{CR}=0.88$ \\
\hline IS2 & 0.89 & 36.76 & & $\mathrm{AVE}=0.80$ \\
\hline \multicolumn{5}{|l|}{ CHRP1 } \\
\hline HR1 & 0.79 & 20.51 & \multirow{4}{*}{0.82} & \multirow{4}{*}{$\begin{array}{c}\mathrm{CR}=0.88 \\
\mathrm{AVE}=0.65\end{array}$} \\
\hline HR2 & 0.85 & 33.22 & & \\
\hline HR3 & 0.80 & 23.29 & & \\
\hline HR4 & 0.77 & 18.19 & & \\
\hline \multicolumn{5}{|l|}{ CHRP2 } \\
\hline HR5 & 0.75 & 13.58 & \multirow[t]{3}{*}{0.79} & \multirow{3}{*}{$\begin{array}{c}\mathrm{CR}=0.87 \\
\mathrm{AVE}=0.71\end{array}$} \\
\hline HR6 & 0.87 & 34.66 & & \\
\hline HR7 & 0.89 & 45.64 & & \\
\hline \multicolumn{5}{|l|}{ Competition $^{\mathrm{b}}$} \\
\hline HC1 & 0.40 & 3.16 & \multirow[t]{2}{*}{ na } & \multirow{2}{*}{ na } \\
\hline HC2 & 0.80 & 3.71 & & \\
\hline \multicolumn{5}{|l|}{ E-business use } \\
\hline EB1 & 0.82 & 24.79 & \multirow{5}{*}{0.90} & \multirow{5}{*}{$\begin{array}{c}\mathrm{CR}=0.92 \\
\mathrm{AVE}=0.72\end{array}$} \\
\hline EB2 & 0.87 & 34.75 & & \\
\hline EB3 & 0.83 & 24.20 & & \\
\hline EB4 & 0.88 & 40.50 & & \\
\hline EB5 & 0.83 & 27.92 & & \\
\hline \multicolumn{5}{|c|}{ Organiz. innovation } \\
\hline OI1 & 0.85 & 29.20 & \multirow[t]{5}{*}{0.87} & \multirow{5}{*}{$\begin{array}{c}\mathrm{CR}=0.90 \\
\mathrm{AVE}=0.67\end{array}$} \\
\hline $\mathrm{OI} 2$ & 0.83 & 26.34 & & \\
\hline OI3 & 0.78 & 17.68 & & \\
\hline OI4 & 0.82 & 21.11 & & \\
\hline OI5 & 0.80 & 18.88 & & \\
\hline \multicolumn{5}{|l|}{ Firm Perf. 1} \\
\hline FP1 & 0.89 & 51.34 & \multirow[t]{3}{*}{0.78} & \multirow{3}{*}{$\begin{array}{c}\mathrm{CR}=0.87 \\
\mathrm{AVE}=0.70\end{array}$} \\
\hline FP2 & 0.86 & 31.48 & & \\
\hline FP3 & 0.75 & 16.16 & & \\
\hline \multicolumn{5}{|l|}{ Firm Perf. 2} \\
\hline FP4 & 0.90 & 54.66 & \multirow{2}{*}{0.74} & $\mathrm{CR}=0.88$ \\
\hline FP5 & 0.87 & 31.07 & & $\mathrm{AVE}=0.79$ \\
\hline
\end{tabular}

Notes: ${ }^{\mathrm{a}} p<0.01$; ${ }^{\mathrm{b}}$ formative construct; CR: Composite reliability; AVE: Average variance extracted na. Cronbach's Alpha, CR and AVE are not applicable to formative constructs. 


\section{Results}

Prior to the hypotheses testing, cross validation (CV)-communality and -redundancy indices assess the quality of the structural model. The mean of the CV-communality indices confirms the global quality of the structural model if the indices are positive for all the blocks, taking into account the measurement model as a whole. In addition, the CVredundancy index offers a metric to evaluate the quality of each structural equation. This index should be positive for all endogenous constructs (Tenenhaus et al. 2008). For this study, since all the latent variables had positive values for cross validation (CV)-redundancy and -communality indexes, the model demonstrated adequate predictive validity and fit. After analyzing the quality of the structural equation, the next step is to test the relations between all constructs. Consistent with Chin (1998), bootstrapping (500 subsamples) generates standard errors and t-values. Figure 2 displays the results of hypotheses $\mathrm{H} 1$ to $\mathrm{H} 4$, showing the path coefficients along with their significance levels. The results of the statistical model offer support for $\mathrm{H} 1, \mathrm{H} 2$, and $\mathrm{H} 4$, and fail to corroborate $\mathrm{H} 3$. In addition, Figure 2 shows the results for hypothesis H5. A variable may be considered a mediator to the extent to which it carries the influence of a given independent variable to a given dependent variable. We conducted three tests to examine the mediating effect of organizational innovation: the Sobel test, the Aroian test, and the Goodman test. Accoding to MacKinnon et al. (1995), the Sobel test and the Aroian test perform best with sample sizes greater than 50 or so. The three tests were all significant at the $\mathrm{p}<0.05$ level (Sobel test statistic: 3.11 ; Aroian test statistic: 3.07; Goodman test statistic: 3.14 ) and, thus, corroborating the mediating effect. Our finding supports a partial mediation effect of organizational innovation between e-business use and firm performance since the effect of e-business use on firm performance shrinks upon the addition of organizational innovation to the model. Thus, results offer partial support for hypothesis H5.

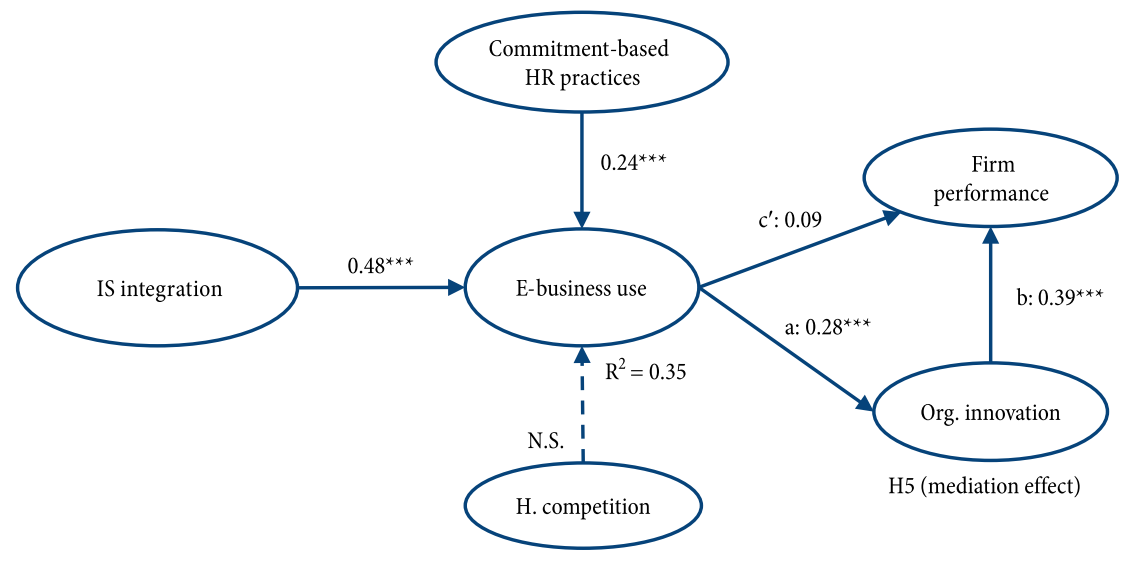

Fig. 2. Results for the model 


\section{Conclusions}

This study, grounded in the TOE theory and the Knowledge-Based View (KBV), shed lights on the factors that affect e-business use and its effect on organizational innovation and firm performance within manufacturing SMEs. The empirical results reveal that factors have differential effects. With regard to the technological context, a positive relationship was found for the relationship between technology integration and the extent of e-business use, being the strongest factor in our model. The first finding confirms existing research (e.g. Zhu et al. 2006; Zhu, Kraemer 2005), which found that technology integration is positively related to the extent of e-business use (Zhu et al. 2006) and positively associated to e-business value (Zhu, Kraemer 2005). Regarding the organizational context, the effect of commitment-based HR practices on the extent of e-business use was analyzed. Results showed a positive relationship between these two constructs. This finding supports recent studies which, though not focusing on the use of e-business along the value chain, found that commitment-based HR practices were significantly related to the use of specific Web technologies for knowledge sharing (Soto-Acosta et al. 2014a, 2014b). Thus, manufacturing SMEs should focus on commitment-based HR practices, rather than on transaction-based HR practices, in order to create a social climate which promotes the use of e-business. With regard to the environmental context, a non-significant relationship was found between horizontal competition and the extent of e-business use. This finding does not support previous support which found that competition intensity is negatively related to the extent of e-business use (Chan et al. 2012; Zhu et al. 2004, 2006) and positively associated with e-business adoption (Del Aguila-Obra, Padilla-Melendez 2008; Wang, Ahmed 2009), demonstrating that e-business use emerges from internal organizational and technological resources rather than from external pressure within manufacturing SMEs.

Furthermore, results suggest a direct positive effect of e-business use on organizational innovation. This finding supports existent literature which concludes that e-business enables and drives organizational innovation (Amit, Zott 2001; Meroño-Cerdán et al. 2008b; Wu, Hisa 2004, 2008; Zwass 2003). Thus, e-business can be used to distribute and share individual experience and innovation throughout the organization (Bhatt et al. 2005) and offer the chance of applying knowledge for the creation of new products and/or services or processes. In addition, e-business intelligence systems may help firms to continuously improve their processes by monitoring the business activity and accessing data analytics timely (Mayeh et al. 2014; Perez-Gonzalez et al. 2014; Vera-Baquero et al. 2013). In sum, the benefits from e-business use, which include efficient information/knowledge sharing and business data analysis as well as working with no distance limitations, are expected to be positively related to innovation. Results also confirm that organizational innovation mediates the relationship between the extent of e-business use and firm performance. This finding supports existing literature suggesting positive direct and indirect links between IT and firm performance (e.g. López-Nicolás, Meroño-Cerdán 2011; Meroño-Cerdán et al. 2008b; Meroño-Cerdan, Soto-Acosta 2007; Pérez-López, Alegre 2012). Thus, manufacturing SMEs should achieve high levels of e-business use in order to obtain organizational innovation which, in turn, may improve their firm performance. 
As any other research, ours suffers from some limitations which can be addressed in future research. First, the sample used was from Spain. It may be possible that the findings could be extrapolated to other countries, since economic and technological development in Spain is similar to other OECD Member countries. However, similar studies in different countries are likely to show different results, especially when considering high IT advanced countries such as the USA, Finland, and Canada. Thus, in future research, a sampling frame that combines firms from different countries could be used in order to provide a more international perspective on the subject. Second, the key informant method was used for data collection. This method, while having its advantages, also suffers from the limitation that the data reflects the opinions of one person. Future studies could consider research designs that allow data collection from multiple respondents within an organization. Third, developing solid instruments in the IT literature is still an ongoing procedure of development, testing and refinement. Although reliability and validity were empirically tested in our data set, further confirmatory studies are necessary to determine the external validity of the results. Particularly, as discussed in the hypotheses section, competition constructs in our study capture horizontal competition, which needs to be enriched in further research to include vertical competition. Fourth, firm performance and organizational innovation measures are subjective in the sense that they were based on Likert-scale responses provided by managers. Thus, it could also be interesting to include objective financial performance and innovation data for measuring these constructs. In addition, future research designs could consider different degrees of innovation (radical and incremental) as well as other forms of innovation such as new business models. Fifth, this research takes a static, cross-sectional picture of contextual factors affecting e-business use, which makes it difficult to address the issue of how contextual factors and their importance may change over years. A longitudinal study could enrich the findings. These suggestions should be taken into account in future studies to increase the validity of our findings.

\section{Acknowledgements}

The authors are very grateful for financial support from the Fundación Cajamurcia.

\section{References}

Aboelmaged, M. G. 2014. Predicting e-readiness at firm-level: an analysis of technological, organizational and environmental (TOE) effects on e-maintenance readiness in manufacturing firms, International Journal of Information Management 34(5): 639-651. http://dx.doi.org/10.1016/j.ijinfomgt.2014.05.002

Acker, A. 2014. The short message service: standards, infrastructure and innovation, Telematics and Informatics 31(4): 559-568. http://dx.doi.org/10.1016/j.tele.2014.01.004

Adamides, E. D.; Karacapilidis, N. 2006. Information technology support for the knowledge and social processes of innovation management, Technovation 26(1): 50-59. http://dx.doi.org/10.1016/j.technovation.2004.07.019

Alavi, M.; Leidner, D. E. 2001. Review: knowledge management and knowledge management systems: conceptual foundations and research issues, MIS Quarterly 25(1): 107-36.

http://dx.doi.org/10.2307/3250961 
Amit, R.; Zott, C. 2001. Value creation in ebusiness, Strategic Management Journal 22: 493-520. http://dx.doi.org/10.1002/smj.187

Antoncic, B.; Hisrich, R. D. 2001. Intrapreneurship: construct refinement and cross-cultural validation, Journal of Business Venturing 16(5): 495-527. http://dx.doi.org/10.1016/S0883-9026(99)00054-3

Aragón-Correa, J. A.; Hurtado-Torres, N. E.; Sharma, S.; García-Morales, V. J. 2008. Environmental strategy and performance in small firms: a resource-based perspective, Journal of Environmental Management 86(1): 88-103. http://dx.doi.org/10.1016/j.jenvman.2006.11.022

Armstrong, C.; Flood, P. C.; Guthrie, J. P.; Liu, W.; Maccurtain, S.; Mkamwa, T. 2010. The impact of diversity and equality management on firm performance: beyond high performance work systems, Human Resource Management 49(6): 997-998. http://dx.doi.org/10.1002/hrm.20391

Bagozzi, R. P.; Yi, Y.; Phillips, L. W. 1991. Assessing construct validity in organizational research, Administrative Science Quarterly 36(3): 421-458. http://dx.doi.org/10.2307/2393203

Barclay, D.; Higgins, C.; Thompson, R. 1995. The partial least squares (PLS) approach to causal modeling: personal computer adoption and use as an illustration, Technology Studies 2(2): 285-309.

Barney, J. B. 1991. Firm resources and sustained competitive advantage, Journal of Management 7: 99-120. http://dx.doi.org/10.1177/014920639101700108

Bayo-Moriones, A.; Lera-Lopez, F. 2007. A firm level analysis of determinants of ICT adoption in Spain, Technovation 27(6/7): 352-366. http://dx.doi.org/10.1016/j.technovation.2007.01.003

Becheikh, N.; Landry, R.; Amara, N. 2006. Lessons from innovation empirical studies in the manufacturing sector: a systematic review of the literature from 1993-2003, Technovation 26: 644-664. http://dx.doi.org/10.1016/j.technovation.2005.06.016

Bhatt, G. D.; Gupta, J. N. D.; Kitchens, F. 2005. An exploratory study of groupware use in the knowledge management process, Journal of Enterprise Information Management 8(1): 28-46. http://dx.doi.org/10.1108/17410390510571475

Bordonaba-Juste, V.; Lucia-Palacios, L.; Polo-Redondo, Y. 2012. Antecedents and consequences of e-business use for European retailers, Internet Research 22(5): 532-550. http://dx.doi.org/10.1108/10662241211271536

Bradford, M.; Earp, J. B.; Grabski, S. 2014. Centralized end-to-end identity and access management and ERP systems: a multi-case analysis using the technology organization environment framework, International Journal of Accounting Information Systems 15(2): 149-165. http://dx.doi.org/10.1016/j.accinf.2014.01.003

Bresnahan, T.; Brynjolfsson, E.; Hitt, L. M. 2002. Information technology, workplace organization and the demand for skilled labor: firm-level evidence, The Quarterly Journal of Economics 117: 339-376. http://dx.doi.org/10.1162/003355302753399526

Brislin, R. W. 1980. Translation and content analysis of oral and written material, in H. C. Triandis, J. W. Berry (Eds.). Handbook of cross-cultural psychology. Boston: Allyn \& Bacon, 349-444.

Chan, F. T. S.; Chong, A.Y.-L.; Zhou, L. 2012. An empirical investigation of factors affecting e-collaboration diffusion in SMEs, International Journal of Production Economics 138(2): 329-344. http://dx.doi.org/10.1016/j.ijpe.2012.04.004

Chang, Y.-Y.; Hughes, M. 2012. Drivers of innovation ambidexterity in small- to medium-sized firms, European Management Journal 30(1): 1-17. http://dx.doi.org/10.1016/j.emj.2011.08.003

Chin, W. W. 1998. The partial least squares approach to structural equation modelling, in G. A. Marcoulides (Ed.). Modern methods for business research. Mahwah, NJ: Lawrence Erlbaum Associates Publisher, 295-336.

Chin, W. W.; Marcolin, B. L.; Newsted, P. R. 2003. A partial least squares latent variable modelling approach for measuring interaction effects: results from a Monte Carlo simulation study and an electronic mail emotion/adoption study, Information Systems Research 14(2): 189-217.

http://dx.doi.org/10.1287/isre.14.2.189.16018 
Chong, A. Y. L.; Ooi, K. B.; Lin, B.; Tang, S. Y. 2009. Influence of interorganizational relationships on SMEs' e-business adoption, Internet Research 19(3): 313-331. http://dx.doi.org/10.1108/10662240910965379

Collins, C. J.; Smith, K. G. 2006. Knowledge exchange and combination: the role of human resource practices in the performance of high-technology firms, Academy of Management Journal 49(3): 544-560. http://dx.doi.org/10.5465/AMJ.2006.21794671

Damanpour, F. 1991. Organizational innovation: a meta-analysis of effects of determinants and moderators, Academy of Management Journal 34(3): 550-590. http://dx.doi.org/10.2307/256406

Darroch, J. 2005. Knowledge management, innovation and firm performance, Journal of Knowledge Management 9(3): 101-115. http://dx.doi.org/10.1108/13673270510602809

Del Aguila-Obra, A.; Padilla-Melendez, A. 2008. Organizational factors affecting Internet technology adoption, Internet Research 16(1): 94-110. http://dx.doi.org/10.1108/10662240610642569

Delery, J. E.; Doty, D. H. 1996. Modes of theorizing in strategic human resource management: test of universalistic contingency and configurational performance predictions, Academy of Management Journal 39(4): 802-835. http://dx.doi.org/10.2307/256713

Devaraj, S.; Kohli, R. 2003. Performance impacts of information technology: is actual usage the missing link?, Management Science 49(3): 273-289. http://dx.doi.org/10.1287/mnsc.49.3.273.12736

Devaraj, S.; Krajewski, L.; Wei, J. C. 2007. Impact of eBusiness technologies on operational performance: the role of production information integration in the supply chain, Journal of Operations Management 25(6): 1199-1216. http://dx.doi.org/10.1016/j.jom.2007.01.002

European Commision. 2013. A recovery on the horizon? Annual report on European SMEs 2012/2013.

Fornell, C.; Larcker, F. D. 1981. Evaluating structural equation models with unobservable variables and measurement error, Journal of Marketing Research 18(1): 39-50. http://dx.doi.org/10.2307/3151312

Fox, S. 2000. Communities of practice, foucault and actor network theory, Journal of Management Studies 37(6): 853-867. http://dx.doi.org/10.1111/1467-6486.00207

García-Peñalvo, F. J.; Colomo-Palacios, R.; Soto-Acosta, P.; Martínez-Conesa, I.; Serradell-López, E. 2011. SemSEDoc: utilización de tecnologías semánticas en el aprovechamiento de los repositorios documentales de los proyectos de desarrollo de software, Information Research 16(4): paper 504.

Grant, R. M. 1996. Toward a knowledge-based theory of the firm, Strategic Management Journal 17: 109-122. http://dx.doi.org/10.1002/smj.4250171110

Grant, R. M. 2002. The knowledge-based view of the firm, in C. W. Choo, N. Bontis (Eds.). The strategic management of intellectual capital and organizational knowledge. New York, NY: Oxford University Press, 133-148.

Gu, V. C.; Cao, Q.; Duan, W. 2012. Unified modeling language (UML) IT adoption - a holistic model of organizational capabilities perspective, Decision Support Systems 54(1): 257-269.

http://dx.doi.org/10.1016/j.dss.2012.05.034

Hair, J. F.; Anderson, R. E.; Tatham, R. L.; Black, W. C. 1998. Multivariate data analysis. 5th ed. London: Prentice-Hall.

He, Z. L.; Wong, P. K. 2004. Exploration vs. exploitation: an empirical test of the ambidexterity hypothesis, Organization Science 15(4): 481-494. http://dx.doi.org/10.1287/orsc.1040.0078

Hoopes, D. G.; Madsen, T. L.; Walker, G. 2003. Guest editors' introduction to the special issue: why is there a resource-based view? Toward a theory of competitive heterogeneity, Strategic Management Journal 24(10): 889-902. http://dx.doi.org/10.1002/smj.356

Hsu, P. F.; Ray, S.; Li-Hsieh, Y. Y. 2014. Examining cloud computing adoption intention, pricing mechanism, and deployment model, International Journal of Information Management 34(4): 474-488. http://dx.doi.org/10.1016/j.ijinfomgt.2014.04.006 
Jardim-Goncalves, R.; Popplewell, K.; Grilo, A. 2012. Sustainable interoperability: the future of Internet based industrial enterprises, Computers in Industry 63(8): 731-738.

http://dx.doi.org/10.1016/j.compind.2012.08.016

Judge, W. Q.; Douglas, T. J. 1998. Performance implications of incorporating natural environmental issues into the strategic planning process: an empirical assessment, Journal of Management Studies 35: 241-262. http://dx.doi.org/10.1111/1467-6486.00092

Kessler, E. H. 2003. Leveraging e-R\&D processes: a knowledge-based view, Technovation 23(12): 905915. http://dx.doi.org/10.1016/S0166-4972(03)00108-1

Kim, S. K.; Lee, B. G.; Park, B. S.; Oh, K. S. 2011. The effect of R\&D, technology commercialization capabilities and innovation performance, Technological and Economic Development of Economy 17(4): 563-578. http://dx.doi.org/10.3846/20294913.2011.603481

Kogut, B.; Zander, U. 1992. Knowledge of the firm, combinative capabilities, and the replication of technology, Organization Science 3(3): 383-397. http://dx.doi.org/10.1287/orsc.3.3.383

Lee, D.; Kim, H. 2014. The effects of network neutrality on the diffusion of new Internet application services, Telematics and Informatics 31(3): 386-396. http://dx.doi.org/10.1016/j.tele.2013.10.001

Lian, J.; Yen, D.; Wang, Y. 2014. An exploratory study to understand the critical factors affecting the decision to adopt cloud computing in Taiwan hospital, International Journal of Information Management 34(1): 28-36. http://dx.doi.org/10.1016/j.ijinfomgt.2013.09.004

Lindell, M. K.; Whitney, D. J. 2001. Accounting for common method variance in cross-sectional research designs, Journal of Applied Psychology 86(1): 114-121. http://dx.doi.org/10.1037/0021-9010.86.1.114

López-Nicolás, C.; Meroño-Cerdán, A. L. 2011. Strategic knowledge management, innovation and performance, International Journal of Information Management 31(6): 502-509. http://dx.doi.org/10.1016/j.ijinfomgt.2011.02.003

Lopez-Nicolas, C.; Soto-Acosta, P. 2010. Analyzing ICT adoption and use effects on knowledge creation: an empirical investigation in SMEs, International Journal of Information Management 30(6): 521-528. http://dx.doi.org/10.1016/j.ijinfomgt.2010.03.004

Lubatkin, M. H.; Simsek, Z.; Ling, Y.; Veiga, J. F. 2006. Ambidexterity and performance in small- to mediumsized firms: the pivotal role of top management team behavioral integration, Journal of Management 32(5): 646-672. http://dx.doi.org/10.1177/0149206306290712

Lucia-Palacios, L.; Bordonaba-Juste, V.; Polo-Redondo, Y.; Grünhagen, M. 2014. E-business implementation and performance: analysis of mediating factors, Internet Research 24(2): 223-245.

http://dx.doi.org/10.1108/IntR-09-2012-0195

MacKinnon, D. P.; Warsi, G.; Dwyer, J. H. 1995. A simulation study of mediated effect measures, Multivariate Behavioral Research 30(1): 41-62. http://dx.doi.org/10.1207/s15327906mbr3001_3

Mahoney, J. T.; Pandian, J. R. 1992. The resource-based view of the firm within the conversation of strategic management, Strategic Management Journal 13(5): 363-380. http://dx.doi.org/10.1002/smj.4250130505

Mayeh, M.; Ramayah, T.; Popa, S. 2014. The role of absorptive capacity in the usage of a complex information system: the case of the enterprise information system, Journal of Universal Computer Science 20(6): 826-841.

Meroño-Cerdan, A.; Soto-Acosta, P. 2005. Examining e-business impact on firm performance through website analysis, International Journal of Electronic Business 3(6): 583-598. http://dx.doi.org/10.1504/IJEB.2005.008537

Meroño-Cerdan, A.; Soto-Acosta, P. 2007. External web content and its influence on organizational performance, European Journal of Information Systems 16(1): 66-80.

http://dx.doi.org/10.1057/palgrave.ejis.3000656 
Meroño-Cerdan, A.; Soto-Acosta, P.; Lopez-Nicolas, C. 2008a. Analyzing collaborative technologies' effect on performance through intranet use orientations, Journal of Enterprise Information Management 21(1): 39-51. http://dx.doi.org/10.1108/17410390810842246

Meroño-Cerdan, A.; Soto-Acosta, P.; Lopez-Nicolas, C. 2008b. How do collaborative technologies affect innovation in SMEs?, International Journal of e-Collaboration 4(4): 33-50. http://dx.doi.org/10.4018/jec.2008100103

Nahapiet, J.; Ghoshal, S. 1998. Social capital, intellectual capital, and the organizational advantage, Academy of Management Review 23(2): 242-266.

Nickerson, J.; Zenger, T. 2004. A knowledge-based theory of the firm: the problem solving perspective, Organization Science 15(6): 617-632. http://dx.doi.org/10.1287/orsc.1040.0093

Nunnally, J. C. 1967. Psychometric theory. New York, NY: McGraw-Hill.

Palacios-Marqués, D.; Soto-Acosta, P.; Merigó, J. M. 2015. Analyzing the effects of technological, organizational and competition factors on Web knowledge exchange in SMEs, Telematics and Informatics 32(1): 23-32. http://dx.doi.org/10.1016/j.tele.2014.08.003

Perez-Gonzalez, D.; Soto-Acosta, P.; Popa, S. 2014. A virtual campus for e-learning inclusion: the case of SVC-G9, Journal of Universal Computer Science 20(2): 240-253.

Pérez-López, S.; Alegre, J. 2012. Information technology competency, knowledge processes and firm performance, Industrial Management \& Data Systems 112(4): 644-662. http://dx.doi.org/10.1108/02635571211225521

Peteraf, M. A. 1993. The cornerstones of competitive advantage: a resource-based view, Strategic Management Journal 14: 179-191. http://dx.doi.org/10.1002/smj.4250140303

Podsakoff, P. M.; Organ, D. W. 1986. Self-reports in organizational research: problems and prospects, Journal of Management 12(4): 531-544. http://dx.doi.org/10.1177/014920638601200408

Porter, M. E. 1985. Competitive advantage. New York, NY: Free Press.

Ramayah, T.; Soto-Acosta, P.; Colomo-Palacios, R.; Gopi, M.; Popa, S. 2014. Explaining the adoption of internet stock trading in Malaysia: comparing models, Asian Journal of Technology Innovation 22(1): 131-151. http://dx.doi.org/10.1080/19761597.2013.873110

Ramdani, B.; Chevers, D.; Williams, D. A. 2013. SMEs' adoption of enterprise applications: a technology-organisation-environment model, Journal of Small Business and Enterprise Development 20(4): 735-753. http://dx.doi.org/10.1108/JSBED-12-2011-0035

Raymond, L.; Bergeron, F.; Blili, S. 2005. The Assimilation of e-business in manufacturing SMEs: determinants and effects on growth and internationalization, Electronic Markets 15(2): 106-118. http://dx.doi.org/10.1080/10196780500083761

San Martín, S.; López-Catalán, B.; Ramón-Jerónimo, M. A. 2012. Factors determining firms’ perceived performance of mobile commerce, Industrial Management \& Data Systems 112(6): 946-963. http://dx.doi.org/10.1108/02635571211238536

Shi, S. 2013. The use of Web 2.0 style technologies among Chinese civil society organizations, Telematics and Informatics 30(4): 346-358. http://dx.doi.org/10.1016/j.tele.2012.04.003

Sila, I. 2013. Factors affecting the adoption of B2B e-commerce technologies, Electronic Commerce Research 13(2): 199-236. http://dx.doi.org/10.1007/s10660-013-9110-7

Soto-Acosta, P.; Casado-Lumbreras, C.; Cabezas-Isla, F. 2010. Shaping human capital in software development teams. The case of mentoring enabled by semantics, IET Software 4(6): 445-452. http://dx.doi.org/10.1049/iet-sen.2010.0087

Soto-Acosta, P.; Colomo-Palacios, R.; Perez-Gonzalez, D. 2011. Examining whether highly e-innovative firms are more e-effective, Informatica 35(4): 481-488.

Soto-Acosta, P.; Colomo-Palacios, R.; Popa, S. 2014a. Web knowledge sharing and its effect on innovation: an empirical investigation in SMEs, Knowledge Management Research \& Practice 12(1): 103-113. http://dx.doi.org/10.1057/kmrp.2013.31 
Soto-Acosta, P.; Meroño-Cerdan, A. 2008. Analyzing e-Business value creation from a resource-based perspective, International Journal of Information Management 28(1): 49-60. http://dx.doi.org/10.1016/j.ijinfomgt.2007.05.001

Soto-Acosta, P.; Perez-Gonzalez, D.; Popa, S. 2014b. Determinants of Web 2.0 technologies for knowledge sharing in SMEs, Service Business 8(3): 425-438. http://dx.doi.org/10.1007/s11628-014-0247-9

Tenenhaus, M.; Esposito, V.; Chatelin, Y.; Lauro, C. 2008. PLS path modelling, Computational Statistics \& Data Analysis 48: 159-205. http://dx.doi.org/10.1016/j.csda.2004.03.005

Teo, T. S. H.; Ranganathan, C.; Dhaliwal, J. 2006. Key dimensions of inhibitors for the deployment of web-based business-to-business electronic commerce, IEEE Transactions on Engineering Management 53(3): 395-411. http://dx.doi.org/10.1109/TEM.2006.878106

Thong, J. Y. L. 1999. An integrated model of information systems adoption in small businesses, Journal of Management Information Systems 15(4): 187-214.

Tornatzky, L. G.; Fleischer, M. 1990. The process of technological innovation. Lexington: Lexington Books.

Tsui, A. S.; Pearce, J. L.; Porter, L. W. 1997. Alternative approaches to the employee-organization relationship: does investment in employees pay off?, Academy of Management Journal 40(5): 10891121. http://dx.doi.org/10.2307/256928

Valkokari, K.; Paasi, J.; Rantala, T. 2012. Managing knowledge within networked innovation, Knowledge Management Research \& Practice 10(1): 27-40. http://dx.doi.org/10.1057/kmrp.2011.39

Vera-Baquero, A.; Colomo-Palacios, R.; Molloy, O. 2013. Business process analytics using a big data approach, IEEE IT Professional 15(6): 29-35. http://dx.doi.org/10.1109/MITP.2013.60

Wang, Y. M.; Wang, Y. S.; Yang, Y. F. 2010. Understanding the determinants of RFID adoption in the manufacturing industry, Technological Forecasting and Social Change 77: 803-815. http://dx.doi.org/10.1016/j.techfore.2010.03.006

Wang, Y.; Ahmed, P. 2009. The moderating effect of the business strategic orientation on e-commerce adoption: evidence from UK family run SMEs, Journal of Strategic Information System 18(1): 16-30. http://dx.doi.org/10.1016/j.jsis.2008.11.001

Wayne, S. J.; Shore, L. M.; Liden, R. C. 1997. Perceived organizational support and leader-member exchange: a social exchange perspective, Academy of Management Journal 40: 82-111. http://dx.doi.org/10.2307/257021

Wu, J. H.; Hisa, T. L. 2004. Analysis of Ecommerce innovation and impact: a hypercube model, Electronic Commerce Research and Applications 3: 389-404. http://dx.doi.org/10.1016/j.elerap.2004.05.002

Wu, J. H.; Hisa, T. L. 2008. Developing ebusiness dynamic capabilities: an analysis of ecommerce innovation from i-, m- to u-commerce, Journal of Organizational Computing and Electronic Commerce 18: 95-111. http://dx.doi.org/10.1080/10919390701807525

Xin, J. Y.; Ramayah, T.; Soto-Acosta, P.; Popa, S.; Ping, T. A. 2014. Analyzing the use of the Web 2.0 for brand awareness and competitive advantage: an empirical study in the Malaysian hospitability industry, Information Systems Management 31(2): 96-103.

http://dx.doi.org/10.1080/10580530.2014.890425

Youndt, M. A.; Snell, S. A.; Dean, J. W.; Lepak, D. P. 1996. Human resource management, manufacturing strategy, and firm performance, Academy of Management Journal 39(4): 836-866. http://dx.doi.org/10.2307/256714

Zhu, K.; Kraemer, K. 2005. Post-adoption variations in usage and value of e-business by organizations: cross-country evidence from the retail industry, Information Systems Research 16(1): 61-84. http://dx.doi.org/10.1287/isre.1050.0045

Zhu, K.; Kraemer, K. L.; Xu, S. 2006. The process of innovation assimilation by firms in different countries: a technology diffusion perspective on e-business, Management Science 52(10): 1557-1576. http://dx.doi.org/10.1287/mnsc.1050.0487 
Zhu, K.; Kraemer, K. L.; Xu, S.; Dedrick, J. 2004. Information technology payoff in e-business environments: an international perspective on value creation of e-business in the financial services industry, Journal of Management Information Systems 21(1): 17-54.

Zhu, K.; Kraemer, K.; Xu, S. 2003. Electronic business adoption by European firms: a cross-country assessment of the facilitators and inhibitors, European Journal of Information Systems 12(4): 251-268. http://dx.doi.org/10.1057/palgrave.ejis.3000475

Zhu, Y.; Li, Y.; Wang, W.; Chen, J. 2010. What leads to the post-implementation success of ERP? An empirical study of the chinese retail industry, International Journal of Information Management 30(3): 265-276. http://dx.doi.org/10.1016/j.ijinfomgt.2009.09.007

Zwass, V. 2003. Electronic commerce and organizational innovation: aspects and opportunities, International Journal of Electronic Commerce 7(3): 7-37.

\section{APPENDIX}

\section{Measures}

\section{Information systems integration}

IS1 Extent to which the website is electronically connected with back-end systems and internal databases.

IS2 Extent to which company databases are electronically connected to that of business partners' (clients, suppliers...) systems and databases.

\section{E-business use}

EB1 Extent to which e-business technologies are used to conduct product design activities. EB2 Extent to which e-business technologies are used to support manufacturing activities. EB3 Extent to which e-business technologies are used to support marketing activities.

EB4 Extent to which e-business technologies are used to support product tracking and distribution.

EB5 Extent to which e-business technologies are used to support procurement activities and coordination with suppliers.

\section{Commitment-based HR practices}

HR1 Our company support employees willing to take further training.

HR 2 Our company helps employees achieving work-like balance.

HR 3 Training programmes are conducted on a regular basis.

HR 4 Employees' interest are taken into account for decision-making.

HR 5 Our company has established career paths.

HR 6 Performance appraisals are conducted on a regular basis.

HR 7 Employees are informed about their performance appraisals.

\section{Horizontal competition}

HC1 Extent of rivalry among competitors in your industry.

HC2 Extent of threat from substitute products in your industry. 


\section{Organizational innovation}

OI1 Number of new or improved products launched to the market is above the average of your industry.

OI2 Number of new or improved processes is above the average of your industry.

OI3 Top management at the company emphasizes the importance of research and development.

OI4 New line of products have been introduced during the last five years.

OI5 Changes introduced in products during the last five years are very important.

\section{Firm performance}

FP1 Earnings growth is above that of your competitors.

FP2 Return on investment is above that of your competitors.

FP3 Market share is above that of your competitors.

FP4 Customer satisfaction is above that of your competitors.

FP5 Customer-perceived quality of your products is above that of your competitors.

Note. All items are rated on five-point Likert-type scales ranging from strongly disagree (1) to strongly agree (5).

Pedro SOTO-ACOSTA is an Associate Professor of Management at the University of Murcia (Spain). He attended Postgraduate Courses in Management at Harvard University (USA) and received his PhD in MIS from University of Murcia. His work has been published in journals such as Behaviour \& Information Technology, Computers in Human Behavior, Enterprise Information Systems, European Journal of Information Systems, European Management Journal, Information Research, International Journal of Information Management, Information Systems Management, Journal of Business Research, Management Decision and Online Information Review, among others. He is an Editorial Board Member and Associate Editor for several international journals and Chairman of various international conferences.

Simona POPA holds a PhD in MIS from the Department of Management and Finance at the University of Murcia, Spain. She received a BA in Accounting and data management from the University Alexandru Ioan Cuza (Iasi, Romania), a Master's in Business Research and a Master's in Sociology Applied to Research from University of Murcia (Spain). Her research interests are in the areas of eBusiness, Management Information Systems, Human-Computer Interaction and Business Information Management. Her work has been published in journals such as International Journal of Information Management, Information Systems Management, Knowledge Management Research \& Practice, Journal of Universal Computer Science and Service Business, among others.

Daniel PALACIOS-MARQUÉS is Professor of Management at the Technical University of Valencia, Spain. He has an MBA in Quality Management and Business Administration. He has published articles in journals such as Tourism Management, Annals of Tourism Research, Small Business Economics, Management Decision, International Journal of Technology Management, Cornell Quarterly Management, Services Industries Journal, Service Business, International Entrepreneurship and Management Journal, Journal of Knowledge Management, Human Resource Management, International Journal of Project Management, Technological and Economic Development of Economy, among others. He has been Editor of the book Connectivity and Knowledge Management in Virtual Organizations, Networking and Developing Interactive Communications. Full editor of Globla Business Perspectives (published by Kluwer/Springer). 